\title{
PANCASILA AND ISLAMIC EDUCATION: THE DERADICALIZATION MODEL OF MADRASAHS BASED ON ISLAMIC BOARDING SCHOOLS IN CENTRAL JAVA
}

\author{
Ihsan \\ Institut Agama Islam Negeri (IAIN) Kudus, Indonesia \\ ihsan@iainkudus.ac.id \\ Ahmad Fatah \\ Institut Agama Islam Negeri (IAIN) Kudus, Indonesia \\ ahmadfatah@iainkudus.ac.id
}

\begin{abstract}
The purpose of this study is to review the deradicalization strategy in religion through strengthening the understanding of Pancasila in the context of Islamic Education at Islamic boarding madrasahs in Central Java. This study involved Madrasah-Pesantren/Madrasahs-Islamic Boarding schools (MP) in the North Coast (Pantura) Region of Central Java, including Madrasah Aliyah (MA) al-Wathoniyah Semarang, MA Qudsiyyah Kudus, MA al-Hidayah Kudus, MA al-Hidayat Lasem Rembang, and MA al-Anwar Sarang Rembang. By employing a qualitative approach through interview and observation data collection methods, this study revealed that the government of the Republic of Indonesia's religious deradicalization program requires support from Islamic boarding schools. One of them is the conceptual support that makes the program effective,
\end{abstract}


referring to deradicalization through Islamic Education (PAI). This deradicalization process is carried out through strengthening Pancasila values integrated through PAI. It is based on the style of radicalism, especially among Muslims who question the national principle's validity of Pancasila in the name of Islam. Pancasila is considered a secular ideology and even kafir because it did not depart from God's revelation. Indeed, this judgment is baseless because the first principle is Belief in the Almighty God, reflecting the value of tawhid. With the existence of tawhid in Pancasila, this national principle is religious in nature, even comprising tawhid. This religious dimension introduction is carried out through Islamic Education in Madrasah-Pesantren (MP) to protect students (santri) and students from the radicalism virus.

Keywords: Pancasila, Islamic Education, Deradicalization, Madrasah, Islamic Boarding School.

\section{A. Introduction}

Radicalism and terrorism in the name of Islam still manifest challenges for national life. The challenges range from the rejection of Pancasila as the national principle, religious intolerance developed both against interreligious and fellow religious groups but with different Islamic madhhab, to the point of suicide bombings in this country. The Government of the Republic of Indonesia has taken various strategic measures, from repressive efforts by arresting terrorism networks to preventive efforts by strengthening anti-terrorism regulations and maintaining religion deradicalization and religious life moderation.

These efforts are deemed ineffective in the development of radical and terrorist understanding among some religious groups. In 2017, a survey conducted by The Alvara Research 
Center exposed a various percentage of Muslims who idealized the Islamic Khilafah state rather than the Unitary State of the Republic of Indonesia (NKRI) based on Pancasila.

Based on the survey, the support for the Khilafah was as much as $15 \%$ among professionals. Meanwhile, $16.8 \%$ of university students and $18.6 \%$ of school students support it. In fact, the State Civil Servants (ASN) occupied the highest percentage among those who support Khilafah at $19.4 \%$. Nevertheless, the percentage of Khilafah supporters is still lower than those supporting Pancasila at 80\%. However, the percentage of $16-19 \%$ cannot be underestimated as it indicated that many Indonesian citizens born in Indonesia, lived under the Indonesian government, and received national education still idealize the form of a state that was not in accordance with the agreement of the nation's founders.

The reasons for rejecting Pancasila and accepting Khilafah are due to a lack of understanding of this nation's ideology. Regarding this, for $19 \%$ of the Khilafah supporters, Pancasila is considered a secular ideology and even kafir or taghut. It is regarded as secular because Pancasila did not explicitly come from the Qur'an. Instead, it was the result of the thought and agreement of the nation's founders. It means that Pancasila is a product of human thoughts. Unlike Islam, the religion is from Allah SWT, which is ideal to be implemented as the national principle.

The assessment that Pancasila is a secular ideology has its historical roots in the Pancasila discourse itself. Since the First Session of the Investigating Committee for Preparatory Work for Independence (BPUPK) on May 29-June 1, 1945, Islamic figures have idealized Islam as the national principle. 
Regarding this, Muhammadiyah leadership, namely Ki Bagoes Hadikusumo, offered Islam as the national principle. He argued that Islam is a religion that calls for unity, nationality, democracy, and justice. Making Islam the national principle does not mean erasing nationalism and society because it has values in line with modern political life principles (Hadikusumo, 2016).

Likewise, when Kiai Wahid Hasyim from Nahldatul Ulama (NU) became a member of the Committee of Nine to formulate the Jakarta Charter on 22 June 1945, Kiai Wahid expressed his agreement on the seven words (in Bahasa Indonesia) "with the obligation to carry out Islamic law for its adherents" as a supplement to the divine precepts. For Kiai Wahid, the inclusion of sharia in the national principle would make Pancasila religious. Thus, Muslims had solid reasons for being a state. It was not only a reason for the state but also a reason for faith. The inclusion of sharia as part of the national principle was strategic because, according to Kiai Wahid, sharia is inclusive, which signifies protecting religious diversity in Indonesia (Harun et al., 1986).

However, Muhammadiyah and NU leaders' views are not automatically radical as today's Islamic national principle's proponents. It is because placing Islam as the national principle is an inevitability for faith as a Muslim. The proof is that when the nationalist and non-Muslim circles' aspirations preferred a national foundation, these Islamic leaders also agreed with this aspiration as it follows the nature of the pluralistic Indonesian society. It was evidenced by the agreement between Ki Bagoes Hadikusumo and Kiai Wahid Hasyim to remove the "seven sharia words" in the Jakarta Charter (Latif, 2011). 
In the Constituent Assembly, the debate was even more heated, in which the view has not only departed from the inevitability of faith as a Muslim but also delegitimized Pancasila. Muhammad Natsir from Masjumi, for example, called Pancasila a secular ideology (la diniyyah) because it did not originate from the Qur'an. He outlined that Pancasila was just a "blank paper," which anyone could interpret with any interpretation. The proposal of the Indonesian Communist Party (PKI) to replace the precepts of One and Only Godhead with Freedom of Religion and Belief, according to Natsir, implied that interpretations contrary to divinity could have a place in Pancasila. For this reason, Natsir offered Islam as the national principle to replace Pancasila (Ma'arif, 2017).

Supporting the Islamic national principle as a substitute for Pancasila has continued until after the Reformation. The activists of ex-Hizbut Tahrir Indonesia (HTI), for example, place Pancasila as a kafir ideology that is incompatible with Islam due to two underlying reasons. First, Pancasila is considered to contain religious pluralism, in which divine precepts protect all existing religions, even though Islam is the true religion. Second, Pancasila contains secular ideologies contrary to Islamism (Islamic ideology). Nationalism, democracy, and socialism are ideologies that ex-HTI deem contradicts Pancasila. Thus, Pancasila must be replaced with Islam because it is a religion and political ideology that comes directly from God (Arif, 2018).

From these facts, the rejection of Pancasila can be viewed as the primary measure for radicalism. The rejection refers to not only the form of the Republic of Indonesia's national state but also Pancasila as the national principle. The reverse 
logic is that if these radical circles can accept Pancasila, the national state-building and the nationalism values will also be accepted. Thus, acceptance of Pancasila is the primary condition for efforts to deradicalize religion. It happens because radicalism arises from a lack of understanding of this nation's ideology. If the understanding of Pancasila is built, then radicalism will logically shift to moderatism.

The process of religious deradicalization can then be organized through strengthening Pancasila's understanding based on strengthening moderate Islamic insights in line with Pancasila values. It can be administered in the context of deradicalization efforts in general and through the educational process, in this case, Islamic Education (PAI). As Islamic religious education, PAI enables moderate Islamic insights' internalization to be delivered through this education. In this regard, strengthening moderate Islamic education is then carried out through strengthening Pancasila education developed through PAI.

Moreover, deradicalization efforts have been carried out by various parties, such as schools, Islamic boarding schools, and universities. In a study conducted by Subhani et al. (2017), Jabal Nur Islamic Boarding School has various strategies to protect its students from radicalism, violence, and fundamentalist ideology by (1) implementing a learning curriculum according to the Ministry of Religion; (2) administering religious education based on the Salafi method (al-kitab al-asfar), which contains the deradicalization concept, and in this way, students are educated to become obedient; (3) maintaining fostering or parenting system for 24 hours; (4) involving students with various extracurricular 
activities, such as calligraphy learning, language department centers, sports activities, and many others (Yani et al., 2018).

Likewise, in the research by Nurdin \& Naqiyyah (2019), to counter radicalism and spread religious moderation, the Salaf al-Anwar Islamic boarding school in Sarang, Rembang, implemented an education system based on the Salaf curriculum, in which the message material was based on turath books. With the kiai's strong credibility, this model effectively instills a moderate attitude for students and the community. In addition, religious moderation in Islamic boarding schools can be applied through the students' attitudes and behavior that are always guided by the two principles of Islamic boarding school thought. First, students must have special knowledge as a provision for themselves and general knowledge to face society. Second, in solving social problems, students must always refer to the four pillars of the nation (Nurdin \& Naqiyyah, 2019).

Meanwhile, Muhsin et al. (2019) reviewed the deradicalization movement and the cultivation of religious moderation in their research that has been conducted at the Surakarta State Islamic Institute (IAIN). The deradicalization movement in higher education was carried out by the Student Islamic Da'wah organization (LDK) IAIN Surakarta through the establishment of LDK Nusantara in forming moderate Islamic cadres, which counteract the radical thinking among students (Muhsin et al., 2019). This pattern is also applied at Gadjah Mada University (UGM) Yogyakarta and State Islamic University (UIN) Sunan Kalijaga Yogyakarta. For instance, (Muhsin, 2019) explained that the Student Organizations of UGM had actively discussed and mapped the pattern of student 
radicalism movements, which would then be followed up by enacting the Minister of Research, Technology, and Higher Education Regulation No. 55 Year 2018 (Muhsin et al., 2019). In addition, UIN Sunan Kalijaga Yogyakarta realized the spirit of deradicalization in the form of campus rules that are full of religious moderation values (Muhsin et al., 2019).

Specifically, Pancasila as the basis of religious education has been previously reviewed. Ridwan (2013) explained that religious education without the Pancasila concept would only build a separatist generation rather thanthe spatrioticgeneration with the national integrity needed by the Indonesian nation. Religious education should promote critical pedagogy that is responsive to the issues of peace, social problems, and social justice, which become an essential part of Pancasila and the needs of the Indonesian nation (Ridwan, 2013). Furthermore, Musthofa (2017) explicates that education based on Pancasila-humanism has several characteristics including (1) respecting religious beliefs, (2) respecting human dignity and human rights, (3) having national insight, (4) respecting freedom democratically, and (5) upholding and enforcing social justice. Therefore, the humanization of Islamic education in Indonesia have to follow and should not give up these values. The Pancasila values are a unified whole, which cannot be separated as the basis of education to form Indonesian people with Pancasila personalities (Musthofa, 2017).

The process of deradicalization through Pancasila education within the framework of Islamic Education is the focus of this paper. As stated, this paper will review the strategy of religious deradicalization through strengthening Pancasila's 
understanding of the field of Islamic Education. Therefore, there are three didactic processes in this education. First, strengthening Pancasila's understanding and strengthening Pancasila is carried out through moderate Islamic insights within the PAI framework. Third, the two didactic processes are organized to achieve the deradicalization of religious understanding among students.

The study's objects were Madrasah-Pesantren (MP) in the North Coast (Pantura) area of Central Java. As a madrasah built on the Islamic boarding school's education culture, MP has proven effective in strengthening moderate Islamic understanding of Pancasila and Islamic Pancasila due to the moderate Islamic tradition of Islamic knowledge from the beginning. To strengthen Pancasila, the moderate Islamic tradition needs to be contextualized in the modern political values that exist in Pancasila.

\section{B. Pancasila and Deradicalization}

Deradicalization means softening the individual radicalism view to be able to accept the action of achieving certain goals through terrorism is illegal, immoral, and cannot be justified. Meanwhile, disengagement refers to social and cognitive changes marked by steps to leave social norms, values, behaviors, and aspirations that were carefully forged when the individual was still a member of a terrorist network. Disengagement indicates adherence to religious values and behavior. In some cases. the individual is usually still involved in other forms of social behaviors to support terrorism, although he or she is no more involved in actual terrorism operations. In this regard, the disengagement 
process consists of two separate parts: physical and psychological (Febriane \& Mariamah, 2013). In other words, disengagement is a gradual process that lasts for years and does not always move forward linearly.

Furthermore, deradicalization combines two terms with different meanings but the same ultimate goal of making radicals want to leave or giving up the acts of radicalism in the form of violence. As a result, deradicalization is the reversal of the radicalization process. Therefore, the rehabilitation program must carefully assess the targeted individuals' radicalization process and develop a reversed course program. For this purpose, it is essential to consider the differences between different types of extremist groups.

Deradicalization usually involves several steps, including the change of values and behavior. Values changes do not always precede behavior changes. Individuals often join extremist groups in the same way, as they may join gangs through social connections to gain a sense of belonging, and only then do they gain extremist views.

At least, three points can be achieved through deradicalization including changing the views of radicals about the Indonesian context as a state of peace, educating radicals to be more self-critical, and having the courage to say "No!" to violence. The parameter set for effective deradicalization from the most feasible to the most difficult to achieve includes (1) achieving openness; (2) acquiring critical thinking; (3) having sense of the context of daar alharb (a state of war) and dar as-salam (a state of peace); (4) possessing empathy for terrorism victims ; (5) releasing from violence; (6) encouraging self-empowerment; (7) maintaining 
continuous learning; (8) having adjustments for the wider community; (9) doing social reintegration; (10) having mental independence (e.g., avoidance of blunt obedience); (11) enhancing tolerance towards outgroups; (12) building good relations with heterogeneous community members; (13) understanding local wisdom; (14) having citizenship; (15) having courage against group pressure; (16) promoting anti-violence messages publicly; (17) possessing resilience in promoting non-violent messages to society; (18) inspiring youth to become agents of change in promoting anti-violence messages in the country (Mareta, 2018).

Achieving openness to people outgroups is not easy, but it is still doable. On the other hand, inspiring youth to become agents of change in promoting anti-violence messages in mass media, online media, or forums is the most challenging stage to be achieved, while some former terror activists have reached this stage. The parameters of effective deradicalization as a central route focusing on counter ideologies are based on careful interpretation of the verses of the Holy text (Hikam, 2016).

Moreover, Pancasila is the national principle and state ideology that becomes the fundamental norm (grundnorm) of Indonesia's constitution and legal system. Apart from being a grundnorm, Pancasila is also a view of life and the nation's ideology. View of life refers to the values held by people in their culture and everyday life. Meanwhile, national ideology is a rational conception practiced both in state systems and institutions, and in the social system and citizens' behavior.

As the basis of a meta-juridical state, Pancasila is not stated in the constitution or legislation products. Textually, 
the editorial precepts are contained in the fourth paragraph of the Preamble to the 1945 Constitution, but what is written in that paragraph is not Pancasila. Pancasila itself is positioned outside the constitution and legislation. The Pancasila position is in the historical realm at the moment of the agreement by the nation founders. Although it is not contained in the constitution, Pancasila's affirmation as the source of all law sources lies in Law No. 12 Year 2011 concerning the Establishment of Legislation (Bo`a, 2018).

In the historical realm, Pancasila's existence has presented in various sessions of the state's basic formulation, which have been held since the BPUPK Session, the Nine Committee, to the Committee for the Preparatory of the Republic of Indonesia's Independence (PPKI) in 1945. Initially, Ir. Soekarno introduced the foundation of the Pancasila state before the BPUPK Session on 1 June 1945. The country's foundation refers to his concept of a philosophical basis (philosophische rondslag) and world view (weltanschauung).

In his speech on 1 June 1945, Bung Karno proposed five principles, which the state founders then refined to form the national principle. The five principles include (1) Nationality, (2) Internationalism or Humanity, (3) Deliberation, (4) Social Welfare, and (5) the Almighty God. The BPUPK Session forum agreed that these formulas become the raw material for the country's basic design. By the Chairman of BPUPK, dr. Radjiman Widiodiningrat, a Committee of Eight, was formed and chaired by Soekarno. In his journey, Soekarno revised this committee because the composition between Islamic and nationalist groups wasnotbalanced in whichthere were too many nationalist groups. Thus, the Committee of Nine was added with the composition of 
four Islamic groups and four nationalist groups, plus Soekarno as chairman and mediator. The Committee of Nine produced the Jakarta Charter on 22 June 1945.

The Jakarta Charter contents are the Preamble draft to the constitution, in which the precept of Pancasila principles is written. All the ideas and conceptions in Soekarno's 1 June speech were approved, and nothing was changed. These ideas are nationality, humanity, deliberation, social justice, and divinity. However, its principles order was changed such as divinity becomes the first precept, nationality occupies the third precept, and humanity is on the second precept. As a result, Soekarno's Pancasila idea was strengthened as the national principle with the additional sentence of, "with the obligation to carry out Islamic law for its adherents". Finally, the "seven words" were deleted based on the aspirations of non-Muslim figures. Pancasila has become the perfect foundation for a state of religious-nationalismt (Latif, 2018).

\section{Deradicalization through Strengthening Pancasila}

The deradicalization strategy through PAI based on strengthening Pancasila education has two strategic positions. First, it directly undermines the radicals' most indepth criticism of Pancasila as the Indonesian state's national principle through the designation of the Islamic nature of Pancasila and NKRI. Indeed, the radicals referred to here are political radicalism (Salafi haroki) and terroristic radicalism (Salafi jihadi), that aspire to establish a khilafah or daulah Islamiyyah. Such ideologies position NKRI as an opposition because it is considered part of the kufr practice due to adopting a non-Islamic political system. 
At this point, as the national principle, Pancasilabecomes a pillar for the form of a nation-state that has dissolved the global unity of the Islamic political area (khilafah). It is also a constitutional basis in upholding people's sovereignty (democracy), which is considered to be injuring God's sovereignty (hakimiyyatullah). It is undoubtedly different from the khilafah or Daulah Islamiyyah, which is based on hakimiyyatullah and places sharia as the state constitution. Thus, Pancasila finally collides with the sharia constitution, NKRI clashes with Islamic daulah, and democracy clashes with God's sovereignty. The logic of clashing Islam and Pancasila remains in the heads of radicals, from HTI to the jihadist movements enforcing sharia, such as MMI, JAT, JAK, MIT, and others (Rokhmad, 2012).

The process of destroying the counter-Pancasila argument is carried out by proving the Islamic or religious dimensions of Pancasila. It means that when radicals reject Pancasila in the name of Islam, the Pancasila-based deradicalization shows the opposite: the Islamic dimension of Pancasila and NKRI.

It can be maintained considering that the Islamic mainstream in Indonesia is moderate and Pancasilaist. For this mainstream understanding, Pancasila is considered Islamic by faith and sharia for several reasons. First, the principle of Almighty Godhead marks the most fundamental value of Islam, namely monotheism, as in verse 1 of Surah alIkhlas: Qul Huwa Allahu Ahad (Say that Allah is One). With the monotheistic principle's position as the first principle underlies all the Pancasila principles, this national principle is faith tawhid. Second, the divine foundation harmonizes the 
constitution, laws, and state policies with Islamic law. Thus, Pancasila, which is monotheistic, does not prohibit Muslims and other religious communities from implementing sharia and the rules of religions in Indonesia.

Third, the four precepts under the divine precepts coordinate with the goals of sharia (maqashid asy-syari'ah). This goal refers to the protection of the five fundamental human rights (al-kulliyat al-khamsah): protecting life (hifdz an-nafs), maintaining religion (hifdz ad-din), maintaining reason (hifdz al-'aql), protecting property (hifdz al-mal), and keeping honor (hifdz al-'irdl). The preservation and protection of these fundamental human rights align with the values of humanity, unity, society, and social justice. In other words, the last precept of Pancasila, social justice, is in accordance with the goal of sharia, which refers to benefit (almashlahat), as Islamic law (fiqh) states, haitsu ma kanat almashlahah fatsamma syar'u Allah wa haitsu ma kana syar'u Allah fatsamma al-mashlahah (Where there is maslahat, there is sharia. Where there is sharia, there is maslahat). This maslahat is what in Pancasila regards as social justice, and in a political (philosophical) language, regards as res publica (common good), which forms the basis for the republican government system.

Fourth, the designation of the Islamic dimension in the nation-state building of the Republic of Indonesia means that the country has received religious approval as part of an Islamic political system. It was organized by members of Islamic boarding schools and moderate Islamic organizations, such as Nahdlatul Ulama (NU), through four stages of Islamic nationalism, namely: 
1. The ratification of the archipelago (Dutch East Indies) as Dar al-Islam (Islamic territory) at the $11^{\text {th }}$ Congress of NU in Banjarmasin (1936). Besides the freedom of the Muslim community in implementing sharia, the reason for this ratification is that Islamic power was established through the Islamic kingdoms throughout the archipelago. As such, it is an Islamic territory, even though a non-Islamic government ruled it. As a result, the santri defended Indonesia from the Allied attacks in the 10 November 1945 war, driven by the Jihad Resolution of K.H. Hasyim Asy'ari.

2. The acceptance of Pancasila and the nation-state by Islamic leaders in the 1945 PPKI Session.

3. The ratification of President Soekarno and all Indonesian Presidents as emerging leaders who have the authority to implement sharia (waly al-amri adl-dlaruri bi asy-syaukah). It is called an emergency because the president is not appointed through the Sunni election mechanism (by the ahl al-halli wa al'aqdi council) and is not an Imam al-A'zham who leads the Islamic world globally. However, even though it is an emergency, the Republic of Indonesia's President has the authority to legalize sharia in the context of the law of marriage, inheritance, waqf, hajj, and other aspects. This ratification was administered at the Alim Ulama National Conference in Cipanas, Bogor, 1954.

4. The loyalty to Pancasila, as a principle of a state that does not replace Islam as faith, through the Alim Ulama National Conference in Situbondo, 1979 (Wahid, 1989). 
With these various ramifications, NKRI is legal in syar'i, so there is no more reason to reject it in the name of Islam. All Islamic arguments for the validity of Pancasila and NKRI are the first stage of Islamic deradicalization based on Pancasila values. The second stage clarifies the relationship between religion and the state within the Pancasila state to straighten out radicals' misconceptions who regard NKRI as a secular state contrary to Islam.

This clarification is carried out by elaborating the relationship between religion and state within Pancasila, which is neither secular nor fundamentalistic. Pancasila has developed a twin tolerance relationship, which religion supports the state, and vice versa. In this way, religious values are not expelled from the public sphere and state administration although they do not become a separate state institution. Radicals do not understand this pattern of twin tolerance relationships because they merely have an oppositional mindset of conflicting secular againts Islamic ideology.

Furthermore, the Pancasila political line has presented a political concept that is more in line with Islamic political values. It is far different from the political system built by the Islamic State in the style of radicalism. This political concept refers to the welfare state, where the end of all state processes is social justice for all people. It aligns with the principle of fiqh, tasahrruf al-imam 'ala ar-ra'iyyah manuthun bi al-mashlahat (Leader's policy is closely related to the welfare of the people). It is also in accordance with maqashid asy-syari'ah and the basic of Islam as a religion of love for all nature (rahmatan li al-'alamin). 
In this context, the goals of state welfare go beyond the state and the form of the state. It means that its existence does not depend on the form of a particular state, as long as the state's form does not violate the principle of state welfare. It happens because state welfare is the essence of politics, which state as an institution try to realize it. The radicals have not thought about the other aspect of the distinction between state and politics and the ontological equation of the two. However, it can be distinguished between articulating both means and goals. It has been done by the mainstream of moderate Muslims who were able to differentiate the means and goals (al-ghayah wa al-wasail). As long as a goal can be achieved, the tool's shape is no longer necessary if it does not violate the existing goals. Furthermore, it can also be applied to understanding the relationship between Islam and the state. Unless the Islamic political goals, namely the benefit of the people (al-mashalih ar-ra'iyyah), can be achieved, the state's form is no longer critical, whether in the form of Islamic or a national state (Abdurrohman, 2018).

Therefore, Pancasila educates citizens and religious communities to fight for political essence because, as Ahmed al-Na'im explained above, state and politics need to be distinguished since the former is a tool, while the latter is a goal. The radicals' struggle to establish an Islamic State neglects political goals because it focuses on the form (state). As a result, some questions emerge about whether to uphold state form or function. In this case, radicals fight for the (Islamic) form, while moderates encourage the state to carry out its functions, reflected in Pancasila. 
With these two general stages of Pancasila-based deradicalization, radicals are educated to understand the nature of Islamic politics through Pancasila. At this point, deradicalization also means citizenship education for radicals through the substance of Islamic teachings in line with Pancasila (Arif, 2018).

\section{Deradicalization and Islamic Religious Education}

One of the efforts to deradicalize religion is to strengthen the understanding of Pancasila through Islamic Education (PAI). It is strategic considering that the understanding of Pancasila through Islamic insight becomes the "closing door" to open the radicalism process. In contrast to Citizenship Education (Pancasila dan Kewarganegaraan, PKn) or Pancasila Education itself, PAI can be an entry point for strengthening Pancasila's understanding through Islamic insights. Both Civics and Pancasila Education are still general in nature and have not thoroughly discussed Pancasila's religious dimension, which has so far not been understood by religious communities.

Deradicalization through PAI with the perspective of Pancasila can be implemented in several steps. The first step is placing Pancasila as the basis of a national state, as well as religious and even tauhidi (tawhid in nature). It is a fact that must be understood, especially by religious communities. Pancasila's religious and tauhidi nature lies in the position of the principle of the belief in the one and only God as the first principle. With this position, the precepts underneath are the operationalization of the divine precepts. At the 1984 NU Muslim Ulama National Conference (Munas) in Situbondo, 
East Java, it was emphasized that the divine precepts in Pancasila reflect the monotheism value. Thus, humanitarian, unity, populist, and social justice principles become the tawhid value practice.

By introducing Pancasila as the national principle that is religious and tauhidi, students will place Pancasila not only as of the national principle and national ideology but also as a formulation of the practice of faith in Allah SWT. This is regarded as the second step of deradicalization through PAI with Pancasila's perspective, namely placing Pancasila as the teaching of tawhid and the practice of the divine values.

In this connection, the divine precepts have presented God's mercy for the nation's life. The divine precepts then represent the principles of tauhid rahamutiyah (God's mercy), which characterize tauhid uluhiyah (God's divinity) and tauhid rububiyah (God's power). God's mercy is perceived as the glorification of God to humans (Q.S. al-Ma'idah [5]: 32), the command to do good amid diversity (Q.S. al-Ma'idah [5]: 48), the command to become a serving leader (Q.S. asy-Syura' [42]: 38), and the command to love the poor (Q.S. al-Ma'un [107]: 1-7). The design of tauhid rahamutiyah in Pancasila is reflected in Q.S. al-Baqarah [2]: 177, where faith must be perfected through compassion for the weak (Arif, 2019).

Thus, practicing Pancasila is not only an obligation of citizens but also Muslims in particular to uphold Islamic values contained in the Qur'an. As explained above, the Pancasila principles contained in the Qur'an refer to the divine values, respect for humans, unity in pluralism, being a populist leader, and loving the poor. All Pancasila valued are ordered by Allah SWT, which eventually become the commitment of the Muslim community to accomplish the commands of the Qur'an. 
Third, through Pancasila's introduction as the practice of religious values, students are then directed to understand and practice what is known as social piety. It is piety that not only saves individuals through God's teachings but also saves society, especially the mustadl'afin. This social piety refers to the values contained in the Surah al-Ma'un, which places rebukers of orphans and people who are reluctant to provide assistance to the poor as religious liars.

In this connection, the values of humanity, unity, populism, and social justice become those values of social piety because they are God's commands. Strengthening the understanding of social piety is indeed the primary paradigm of Pancasila, which places all its values to realize social justice. Thus, the awareness of Pancasila education based on Islamic education is social piety, giving birth to other forms of piety, such as national and democratic piety. It means that students who understand and practice social piety will automatically have a national and democratic ethos that manifests Islamic values.

\section{E. Reformulation of Islamic Religious Education}

In this context, PAI needs to reformulate the paradigm of Islamic education from a formalistic religion to a humanistic religion. The material taught in the educational process does not only refer to learning about the Islamic doctrine but needs to broaden further the horizon of insight towards the primary goal of Islamic sharia (maqashid asy-syari'ah). The primary purpose of sharia, which refers to the protection of basic things (dlaruriyyah) in human life, namely religion, life, thoughts, descent, and property, needs to be introduced 
to students to find the humanistic dimension in religion (Karwadi, 2014). Thus, it is not marginalizing the sharia doctrine, but its understanding is expanded to achieve the knowledge of the maqashid asy-syari'ah.

In the context of maqashid asy-syari'ah, Pancasila's values can be understood within the framework of Islamic doctrine. The protection of these dlaruriyyah matters is part of the values of Pancasila. The One and Only Godhead precepts are meta-juridical principles for protecting religious rights (hifdz ad-din). Just and Civilized Humanity Precepts contain protection of Human Rights (HAM), in which things are protected by maqashid asy-syari'ah, such as the right to life (hifdz an-nafs), the right to think (hifdz al-'aql), hereditary rights (hifdz an-nasl), and property rights (hifdz al-'irdl). Even in Pancasila, the right to property ownership is placed in the context of social equity as taught by the zakat command (Masduqi, 2013).

By introducing maqashid asy-syari'ah to students, they will have a normative closeness to the Pancasila values. It is different if, from the beginning, what students recognize is the formal sharia doctrine, which refers to the commandment of worship along with the products of the classical Islamic law that are not introduced through humanistic and nationalistic perspectives. It is what makes students and Muslims exposed to radicalism directly confront Pancasila and Islamic sharia in contradictions, even though the sharia substance is manifested in the Pancasila values.

Within this framework, the process of strengthening Pancasila through PAI to achieve religious deradicalization process can be understood through the following chart. 

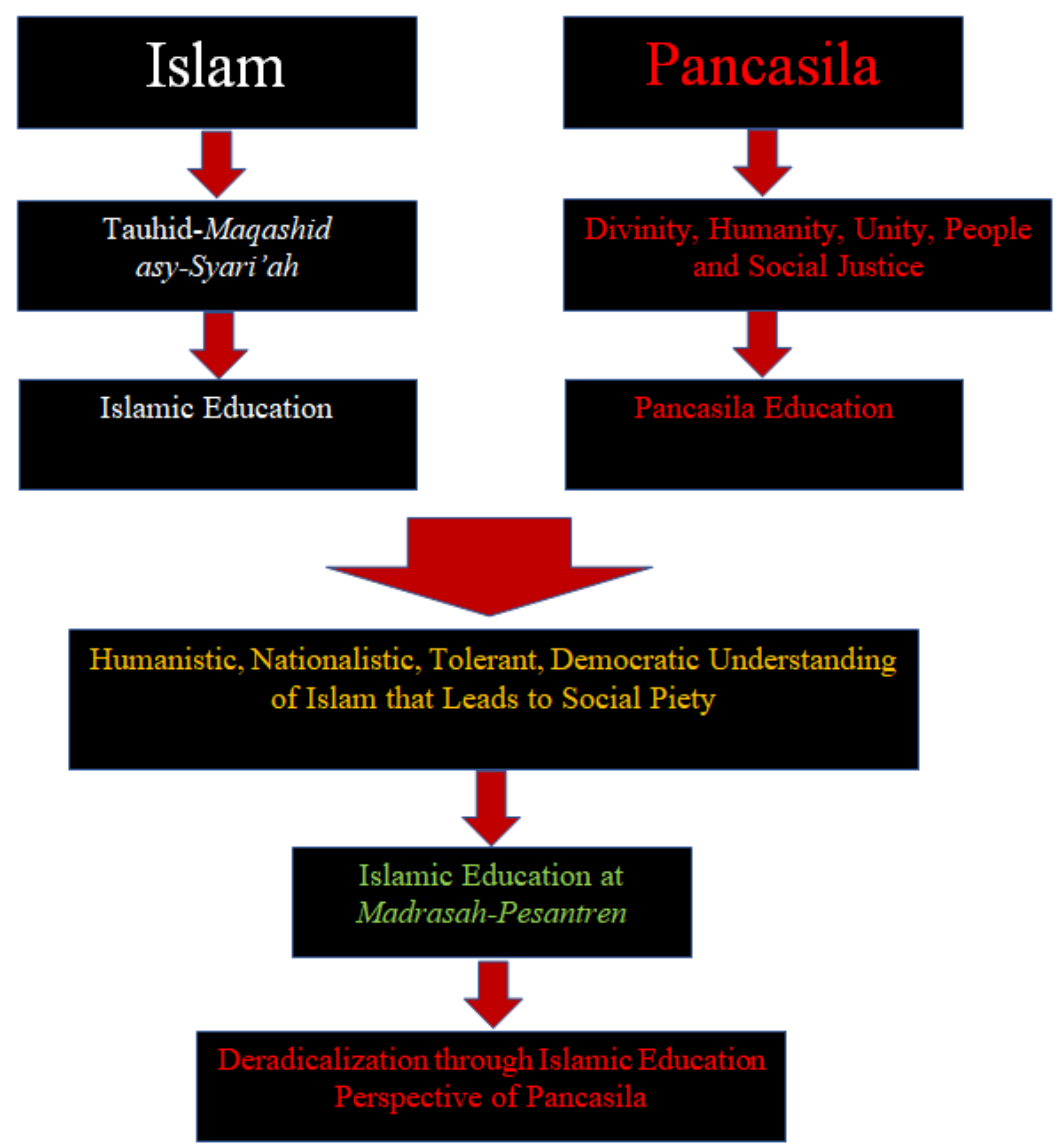

Figure 1

Deradicalization Process through Islamic Education Perspective of Pancasila

From the chart above, it can be understood that Pancasila education through PAI is regarded as an effort to place Islam and Pancasila in a harmonious position. In this harmonious position, both Pancasila and Islam have similar values. Islam has tawhid and maqashid asy-syari'ah values 
(Qodir, 2013; Muqoyyidin, 2017). Tawhid is the main aqidah in Islam, which is practiced through sharia to achieve maqashid asy-syari'ah. Meanwhile, Pancasila contains the value of One God (tawhid in the Islamic faith), which is practiced through the values of humanity, unity, populism, and social justice. The values under this divinity share a vision with maqashid asysyari'ah because these values are also expressed in the Qur'an (Abdurrohman, 2018).

Indeed, in this harmony of values, Islam is superior to Pancasila. Therefore, Pancasila is an objectivation of Islamic values, by which Islamic values are objectivated or manifested into the nation's life and state through Pancasila.

The primary material of PAI is the effort to harmonize Islam and Pancasila through the alignment of tawhid and maqashid asy-syari'ah with Pancasila's divine values. It indicates that PAI becomes a medium for Pancasila education to form students' Islamic understanding of Pancasila. The Islamic understanding of Pancasila refers to an understanding that is humanistic, nationalistic, tolerant, democratic, which leads to an ethos of social piety. This social piety ethos is the pre-condition for realizing social justice, which is the primary goal of Pancasila and Islam.

Within this framework, Madrasah-Pesantren (MP) has become a strategic educational institution for strengthening Pancasila through PAI. Based on the research conducted by the author in several MPs, including Madrasah Aliyah (MA) alWathoniyah Semarang, MA Qudsiyyah Kudus, MA al-Hidayah Kudus, MA al-Hidayat Lasem, and MA al-Anwar Sarang Rembang, the potential for PAI was found to be realized. 
Referring to the institution's vision and mission in the five madrasahs, as a whole, they aim to form students' personalities who can internalize religious values in the style of ahli Sunnah wal jamaah in their daily lives. Even the early establishment of the MA al-Wathoniyyah, previously known as al-Irsyad Islamic boarding school, was later changed to Ma'had Tafsir wa Sunnah al-Itqon to counter the sect that seemed exclusive, as expressed by K.H. M. Sholeh (Sholeh, 2018).

\begin{abstract}
“In the era of Kiai Haris' leadership, measures were taken to improve and specialize in the curriculum structure of Islamic boarding schools, which later inspired the change of name from al-Irsyad to Ma'had Tafsir wa Sunnah Al-Itqon, precisely in 1984. The name change was to avoid the existence of a resemblance under the name of al-Irsyad, an exclusive Islamic sect. According to him, it was less relevant to the culture and nature of Islamic boarding schools, which are known to be inclusive."
\end{abstract}

It indicates that preventing or anticipating sects that are exclusive senses, including radical ones, is something that the madrasah's founders have thoroughly considered previously.

Providing a broad and deep understanding of religion is also regarded as a measure to avoid the exclusive sect. Likewise, K.H. Fathur Rahman (Rahman, 2019) stated that Madrasah Qudsiyyah, which aims at-tafaqquh fi ad-din, is actualized in strengthening PAI subjects, such as tafsir, hadith, akhlaq (morality), fiqh, tarikh, and others, by using reference material/Salaf books and with learning systems/models as implemented at the boarding school. The implementation ensures students' understanding of religion to be perfect to avoid being exclusive. 
From the vision and mission, it is then aligned with learning tools, such as the development of lesson plans (RPP) and others, as conveyed by H. Muhyiddin: (Muhyiddin, 2020)

"Actually, the form of internalizing Pancasila values in all subjects, including PAI, can be developed in the preparation of lesson plans as a reference for learning activities, starting from core competencies that cover spiritual values, social knowledge, and skills. Not to mention, the arrangement uses the $21^{\text {st }}$ century learning characteristics, where the main thing is strengthening character education."

As listed in the lesson plan development, the strengthening of Pancasila values through PAI is actualized during the learning process following the basic competencies of each subject of the PAI cluster, such as appreciating the importance of tolerant (tasamuh) and moderate (tawassuth) behavior teachings to realize the ummah's unity and integrity, both internal and external moderation. For instance, moderate internal behavior can be seen from understanding the law of fiqh with various opinions on a law. In this case, students are taught and given an understanding of the differences between the old fiqh experts so that religious fanaticism does not occur. It is the madrasah's effort in producing moderate student output. Fathur Rahman also said that in understanding the differences in fiqh law, MA Qudsiyyah provides additional subjects of classical books to enrich and strengthen fiqh subjects, as the PAI cluster.

Another example of the basic competencies of the PAI cluster material is practicing tolerant attitudes and respecting differences by comparing the arguments and opinions of schools of kalam about the position of God, the understanding 
of the verses about democracy and deliberation, and many others. Teachers not only teach these values during the learning process but also outside the learning process, as a practical implementation of what is taught and understood to students.

Based on the interview results with the caretaker of the Islamic boarding school and the Head of Madrasah Aliyah alHidayat Lasem Rembang, K.H. Muhammad Zaim, he stated:

"To instill the tolerance values, our institution did not plan directly. However, we provide examples of behaviors that reflect these values, such as being tolerant toward Chinese descent. Therefore, students see firsthand what the elders are doing."

That Al-Qudwah al-Hasanah is a real example implemented and portrayed by the elders in the madrasah. In this case, one thing that cannot be disrupted from the world of madrasah and Islamic boarding schools is the existence of ulama figures who always provide institutional guidance and quality education. With the existence of these figures, it is evident that the cultivation of morals has always been the main focus. This is because the ulama has always been role models for the people, role models for the community, and guardians of the nation's morals in maintaining ukhuwah Islamiyah.

In addition, a compelling concept of al-Qudwah alHasanah is conveyed by K.H. Maimoen Zubair, the Head of MA al-Anwar Sarang Rembang, who is the grandson of K.H. Ahmad Zaki Mubarok as the caretaker of the Al-Anwar Islamic Boarding School Sarang Rembang. He gave the meaning of the independence day of Indonesia during 17 August/8 Ramadan. Meanwhile, Rasulullah SAW was appointed as a prophet on 17 Ramadan/8 August when he first received the revelation. 
The $1^{\text {th }}$ indicates 17 rakaahs and 17 pillars of prayer. Meanwhile, the month of August or the eighth month signifies the closeness of a servant to Allah. The meaning is that when individuals prostrate, seven limbs touch the ground, plus one heart that is humbled in the presence of Allah SWT. It is the best position of a servant to the Lord. When their hearts are pure/good, then all their deeds are good, and vice versa.

The number eight also explains why people are rejected in hell and why he goes to heaven. In the prostration, K.H. Maimoen Zubair explained the seven repellents of hell, including the forehead, two hands, two knees, and two feet. "Tujuh ini sebagai penolak neraka, karena pintu neraka ada tujuh [These seven are a repellent to hell because there are seven gates to hell]," he said. "Ditambah satu lagi, jika kita ingin masuk surga harus ingat sama Allah. Jadi, jumlahnya genap delapan, karena delapan ini merupakan jumlah pintu surga. [Plus, one more. If we want to go to heaven, we must remember Allah. Thus, the number is exactly eight to represent the number of the gates of heaven]."

Furthermore, the year 45 is like five fingers, of which four are pillars and will be perfected by the presence of five. For example, eating food by hand can be done using the index, middle, ring, and little fingers, but it will not be easy without the thumb.

The number 45 also implies that every Muslim must recite the shahada four times and five times. Four times at night are at Maghrib and Isha. Five times during the day are at Fajr, Zhuhur, and Asr. "Jadi, ini menunjukkan bahwa negara Islam itu tidak ada, yang ada adalah negara mayoritas Islam, 
yakni Indonesia. [Thus, it shows that there is no Islamic state but a Muslim-majority country, namely Indonesia]."

Besides, the Kaaba stands firmly on four pillars. Indonesia also has four pillars, namely PBNU (Pancasila, Bhinneka Tunggal Ika [Unity in Diversity], NKRI [Unitary State of the Republic of Indonesia], and the Constitution).

These things are always promoted firmly by the students to instill the spirit of nationalism, which can alleviate the radical attitude as taught by their elders in the form of alQudwah al-Hasanah.

Indeed, the PAI taught in several MPs refers to conventional PAI lessons. However, the educational process was different because it was supported by the pesantren's Islamic culture-based education (Huda, 2018). Thus, PAI lessons in madrasah are then refined by various recitations at the pesantren, strengthening the PAI lessons. The pesantren education culture refers to the methodological education pattern (manhaji) with its crown, the Islamic law philosophy (ushul fiqh) (Musyarrofah, 2018). Through the study of ushul fiqh, several MPs in the Pantura area have trained santristudents to apply rational thoughts in reading the Holy text (nash) to contextualize religion into the society, nation, and state lives.

Coupled with the MP founders' national activism, MPs, such as Madrasah Qudsiyyah, which has K.H.R. Asnawi (18611959), are considered a focal point for regenerating moderate Muslims who become a stronghold for Pancasila and the Republic of Indonesia. As the founder of Madrasah Qudsiyyah and NU founder, Kiai Asnawi has laid the foundations of Islamic nationalism. One of his legacies is Sholawat Asnawiyah, which 
was composed in 1925. Apart from offering praises to Allah SWT and the Prophet Muhammad SAW, this prayer also protects the Indonesian nation from colonialism. One of the lyrics, "Aman aman aman aman, Indonesia Raya aman. Amin amin amin amin Ya Rabbi Rabbal 'Alamin." By praying for the security of this nation, students are taught to love the country as a manifestation of faith.

\section{F. Conclusion}

The religious deradicalization program launched by the Government of the Republic of Indonesia should include strategic measures in strengthening Pancasila values through Islamic Education (PAI). It is very strategic considering that PAI is legally applied in our national education system as an Islamic religious education subject. The process of Islamic radicalization that develops, especially in higher education environments, can be hindered if students at madrasah have been educated by moderate Islamic understanding through Pancasila education based on PAI, or PAI based on the Pancasila paradigm. It is needed so that students do not experience a shock about the Islamic discourses when they enter universities as a "soft market" to penetrate the transnational ideology of Islamism.

It is time for deradicalization policymakers (National Counterterrorism Agency), Pancasila national development (Pancasila Ideology Development Agency), the Ministry of Religious Affairs, and the Ministry of Education and Culture to adopt this strategy. Strengthening moderate Islamic ideology must be followed by the efforts of strengthening the Pancasila ideology. Likewise, strengthening the Pancasila 
ideology must be carried out by strengthening moderate Islamic ideology. In this case, the practice of Islamic Education in Madrasah-Pesantren in Pantura can be a vital reference to be utilized as a pilot project for this immensely urgent national education agenda.

\section{REFERENCES}

Abdurrohman, A. (2018). Deradikalisasi pembelajaran pendidikan agama Islam (PAI) model keberagamaan inklusif di kalangan siswa SMA. Jurnal Schemata, 7(2): 111-127. https://doi.org/10.20414/schemata.v7i2.514

Arif, S. (2018). Islam, Pancasila, dan deradikalisasi: Meneguhkan nilai Keindonesiaan. Jakarta: PT Elex Media Komputindo.

Arif, S. (2019). Penguatan Pancasila untuk ASN. Media Indonesia. https://mediaindonesia.com/opini/275963/ penguatan-pancasila-untuk-asn.

Bo'a, F, Y. (2018). Pancasila sebagai Sumber Hukum dalam Sistem Hukum Nasional, Jurnal Konstitusi, 15(1): 2729. https://doi.org/10.31078/jk1512.

Febriane, S., \& Mariamah. (2013). Keberhasilan Semu Deradikalisasi Di Indonesia, Global: Jurnal Politik Internasional,15(2):137-164.https://doi.org/10.7454/ global.v15i2.34

Hadikusumo, K. B. (2016). Lahirnya Undang-Undang Dasar 1945. Badan Penerbit Fakultas Hukum Universitas Indonesia. 
Harun, H., Shaleh, M., \& Mulkhan, A. M. (1986). Latar belakang Ummat Islam menerima Pancasila sebagai asas tunggal. Yogyakarta: Aquarius.

Hikam, M. A. S. (2016). Deradikalisasi: Peran masyarakat sipil Indonesia membendung radikalisme. Kompas.

Huda, M. (2018). Eksistensi pesantren dan deradikalisasi pendidikan Islam di Indonesia. Fokus: Jurnal Keislaman dan Kemasyarakatan, 3(1): 85-109. http://dx.doi. org/10.29240/jf.v3i1.458

Karwadi, K. (2014). Deradikalisasi pemahaman ajaran Islam. Al-Tahrir: Jurnal Pemikiran Islam, 14(1), 139-156. https://doi.org/10.21154/al-tahrir.v14i1.71

Latif, Y. (2011). Negara paripurna: Historisitas, rasionalitas, dan aktualitas Pancasila. Jakatra: PT Gramedia Pustaka Utama.

Latif, Y. (2018). Wawasan Pancasila: Bintang penuntun untuk pembudayaan. Jakarta: Mizan.

Mareta, J. (2018). Rehabilitasi Dalam Upaya Deradikalisasi Narapidana Terorisme, Masalah-Masalah Hukum, 47(4): 338-356. https://doi.org/110.14710/ mmh.47.4.2018.338-356

Ma'arif, A. S. (2017). Islam dan Pancasila sebagai Dasar Negara (Islam and Pancasila as The National Principle). Bandung: Mizan.

Masduqi, I. (2013). Deradikalisasi pendidikan Islam berbasis khasanah pesantren. Jurnal Pendidikan Islam, 2(1): 1-20. https://doi.org/10.14421/jpi.2013.21.1-20. 
Muhsin, I. (2019). Ideology of Pancasila versus Islamism: Measuring actions and reactions of campus organs to Permenristekdikti No. 55 of 2018 in UGM and UIN Yogyakarta. ADDIN 13(2): 215-246. http://dx.doi. org/10.21043/addin.v13i2.7010

Muhsin, I., Rochmawati, N., \& Huda, M. C.. (2019). Revolution of Islamic proselytizing organization: From Islamism to moderate". QIJIS: Qudus International Journal of Islamic Studies 7(1): 45-70. http://dx.doi.org/10.21043/qijis. v7i1.5076

Muqoyyidin, A. W. (2013). Deradikalisasi Islam dan Tantangannya di Indonesia. Annual International Conference on Islamic Studies (AICIS).

Musthofa (2017). Pendidikan Islam perspektif HumanismePancasila. Jurnal Tarbiyah 24(1): 157-181. http:// dx.doi.org/10.30829/tar.v24i1.129

Musyarrofah, M. (2018). Deradikalisasi melalui pendidikan karakter berbasis khazanah pesantren. Jurnal Mudarrisuna, 8(1): 46-59. http://dx.doi.org/10.22373/ jm.v8i1.2785

Nurdin, A., \& Naqiyyah, M. S. (2019). Model moderasi beragama berbasis pesantren salaf. Islamica: Jurnal Studi Keislaman, 14(1): 82-102. https://doi.org/10.15642/ islamica.2019.14.1.82-102

Ridwan, N. K. (2013). Pancasila dan deradikalisasi berbasis agama. Jurnal Pendidikan Islam 2(1): 173-196. https:// doi.org/10.14421/jpi.2013.21.173-196

Rokhmad, A. (2012). Radikalisme Islam dan upaya deradikalisasi paham radikal. Walisongo, 20(1): 79-114. https://doi.org/10.21580/ws.20.1.185 
Subhani, A. Y., Arifin, A., Aisyah, T., Kamaruddin, K., \& Alfiady, T. (2017). Student radicalism ideology prevention strategy: A study at an Islamic boarding school in Jabal Nur, North Aceh, Indonesia. Proceedings of MICoMS 2017 (Emerald Reach Proceedings Series, Vol. 1), Emerald Publishing Limited, Bingley: 401-407. https://doi. org/10.1108/978-1-78756-793-1-00019

Wahid, A. (1989). Agama, negara, dan sikap moderat NU. In E. M. Sitompul, NU dan Pancasila. Jakarta: Sinar Harapan. 